\title{
Proving Pathogencity of Leveillula taurica Causing Powdery Mildew of Chilli
}

\author{
Mahmad Haneef Peshama ${ }^{1 *}$, M.S. Dadke ${ }^{1}$, B.P. Dandnaik ${ }^{1}$ and B. Zaheer Ahamed ${ }^{2}$ \\ ${ }^{1}$ Department of Plant Pathology College of Agriculture Latur Vasantrao Naik \\ Marathwada Krishi Vidyapeeth Parbhani-431 402, (M.S), India \\ ${ }^{2}$ SMS, KVK, Kalaburgi, UAS Raichur, Karnataka, India \\ *Corresponding author
}

\section{A B S T R A C T}

\begin{tabular}{|l|}
\hline Key w or d s \\
Chilli, Leaf, \\
$\begin{array}{l}\text { Pathogenicity, } \\
\text { Powdery mildew. }\end{array}$ \\
\hline Article Info \\
\hline $\begin{array}{l}\text { Accepted: } \\
\text { 15 October } 2017 \\
\text { Available Online: } \\
10 \text { December } 2017\end{array}$ \\
\hline
\end{tabular}

Pathogenicity of Leveillula taurica Lev.(Arn) was proved on the chilli culti var Parbhani Tejas under controlled conditions in screen house during 2014 and 2015. Typical symptoms were observed within ten to fifteen days after inoculation. After 25 days, as the leaves grow, the number of white tuft increased and coalesced giving the upper side a light greenish yellow, chlorotic spot. In mature leaves the infected veins of the leaf turns somewhat wetted appearance, thus upper side a light greenish yellow, cholorsis. Pathogenicity was proved In vitro. Based on typical symptoms on the foliage, microscopic observations and pathogenicity test; the pathogen has been identified as Leviellula taurica, the cause of powdery mildew of chilli.

\section{Introduction}

Chilli (Capsicum annum L.), belongs to the family Solanaceae is an important spice cum vegetable crop of the world. It is believed to be originated from South America during $15^{\text {th }}$ Century (Pickersgill, 1997).

The fungus causing powdery mildew is an obligate pathogen. The disease is characterized by yellowing on the upper surface of the foliage with a whitish powdery mass on the corresponding lower surface. In severe cases whitish mass develops on both the surfaces which resulted in premature defoliation (Jharia et al., 1978). The fungus causing powdery mildew in chilli appears first on the older leaves and then progresses towards younger leaves. Chloratic spots were noticed on the upper surface of leaves while the corresponding lower surface was covered with white to grey powdery growth of the fungus leading to necrotic spots on lower surface.

Heavy infection leads to leaf shedding resulting in heavy yield losses due to reduction in size and number of fruits, these necrotic lesions gradually turned brownish black with the appearance of fungal fructification stunting of plants followed by fruit drop (Blazquez, 1976). 


\section{Symptomatology}

The most common symptoms were found on the lower side of leaves as brown spot which subsequently covered with whitish growth. The symptoms of the disease were yellow chloratic spots on the upper surface of oldest leaves. White sporulating areas showing abundant production of conidia were visible on the lower surface of leaves. In severe cases whitish mass seen on upper surface of leaves also. Under severe cases defoliation of infected leaves were occurred. Severely affected plants were completely defoliated. Similar symptoms of powdery mildew incited by Leviellula taurica Lev. (Arn) reported by several research workers like. Correll et al., (1987), Cerkauskas et al., (1999), Koike and Beckman (2002) reported that on calla lilly, the powdery mildew symptoms consisted of chloratic spots on leaves. The morphological characters like mycelium, conidiophores, and conidia of the fungus resembled very closely with Leveillula taurica, hence the causal fungus was identified as Leveillula taurica (Lev.) Arn (Fig. 1).

\section{Materials and Methods}

Diseased samples showing typical symptoms of chilli powdery mildew caused by
Leveillula taurica were collected and pathogenicity was proved by transferring Oidea from infected to healthy chilli plant of cultivar Parbhani Tejas, grown in earthen pots.

In the green house, the pathogenicity of the fungus was tested on 60 day old healthy chilli plants of cultivar Parbhani Tejas. Inoculum was collected from farmer's field. The plants were grown individually in earthen pots, containing a mixture of sand and soil (1:1). Plants were covered with plastic bags for twelve hours after inoculation

\section{Results and Discussion}

In the green house, the pathogenicity was proved by transferring Oidea from infected to healthy chilli plant of cultivar Parbhani tejas, grown in earthen pots. Symptoms developed were recorded after 10-15 day after inoculation and typical powdery mildew symptoms were observed as white tuft. Powdery growth covered the entire lower surface of leaves after two of inoculation (Fig. 2). Pathogenicity of Levillula taurica was proved earlier by several workers like Blazquez (1976), Liu Aiyan (2002), Sudha and Lakshamanan (2009) and Sampangi et al., (2010).

Fig.1 Microphotograph showing typical spores of Leveillula taurica causing chill powdery mildew
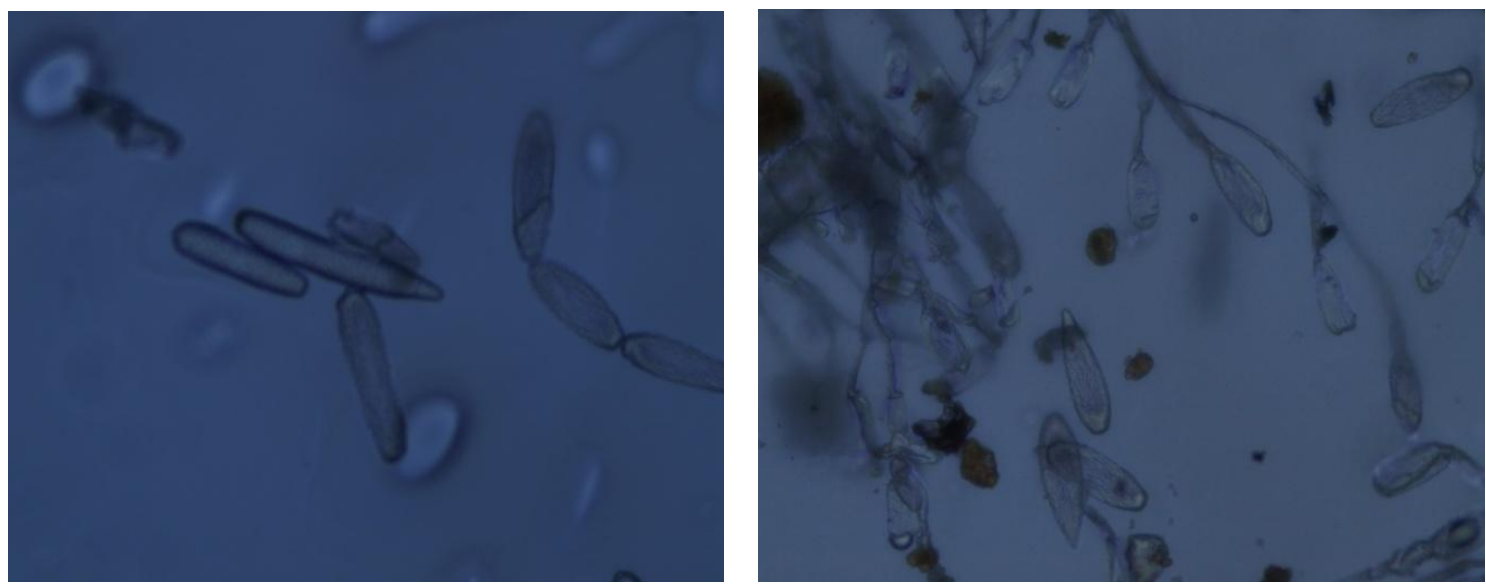

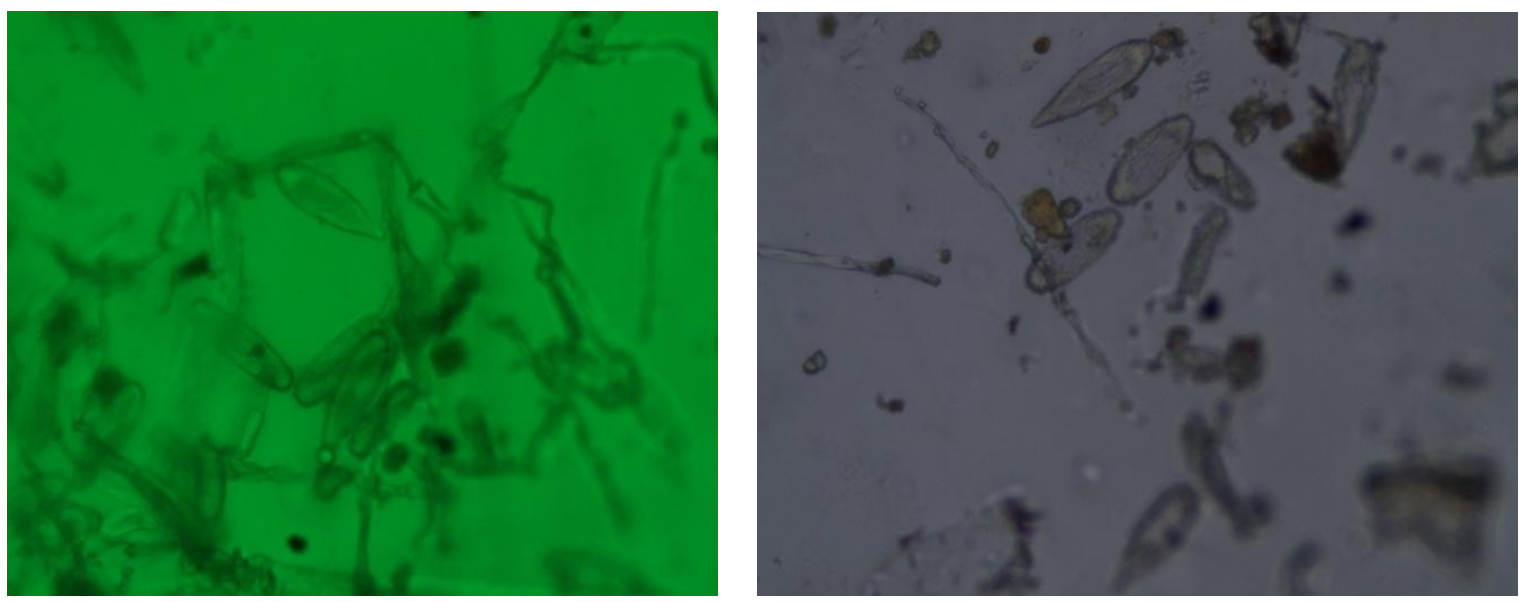

Fig.2 Pathogenicity test of Leveillula taurica on chilli powdery mildew

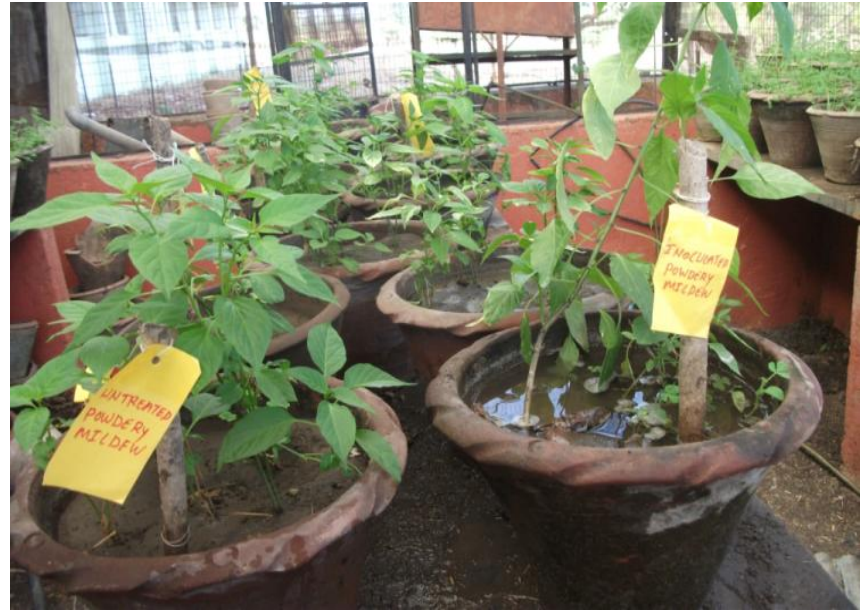

Uninoculated

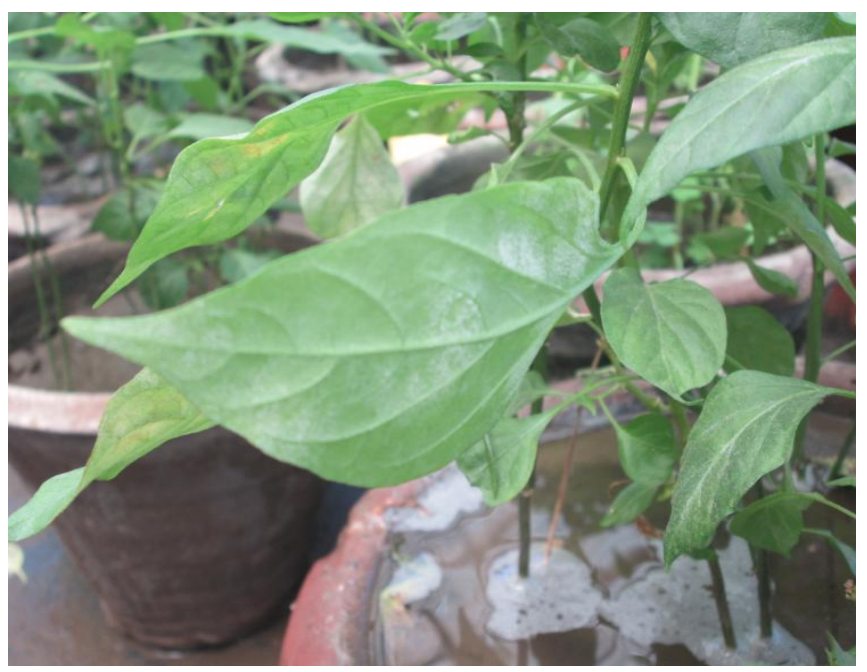

Inoculated

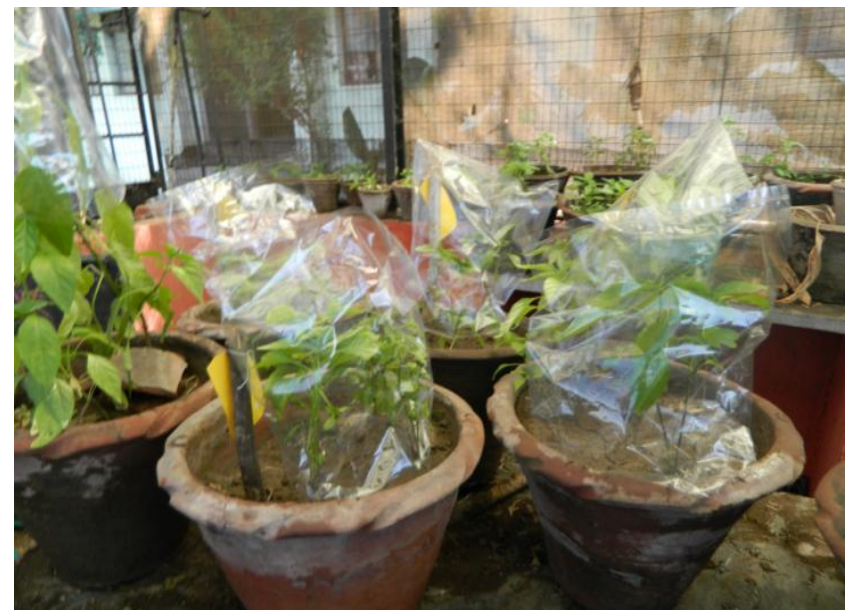

Polythene covering

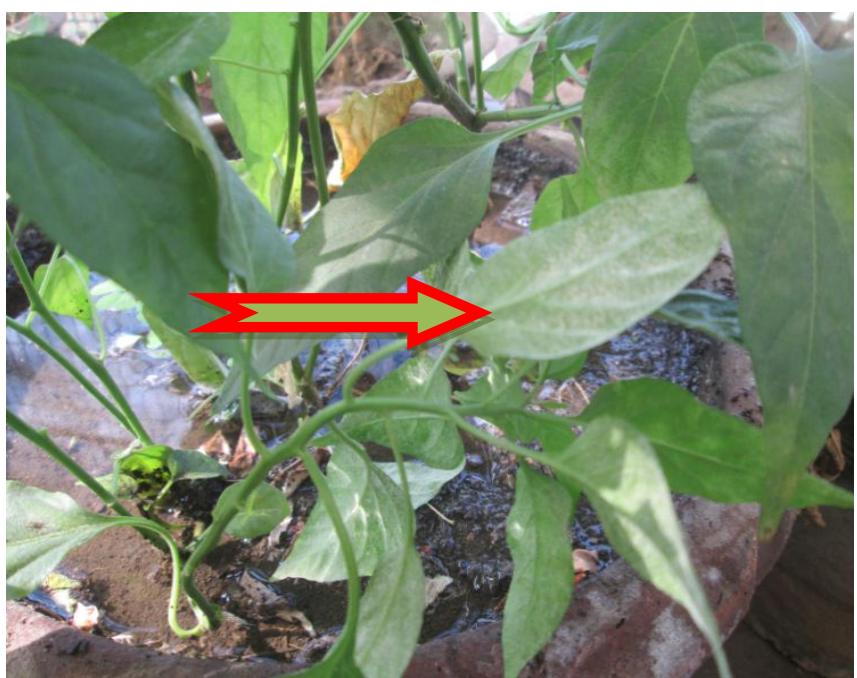

Final symptoms 
Pathogenicity of Leveillula taurica Lev. (Arn) was proved on the susceptible cultivar of chilli under controlled condition in screen houses typical symptoms were observed within ten to fifteen days after inoculation. After 25 days, as the leaves grow, the number of white tuft increased, coalesced giving the upper side a light greenish yellow, cholorsis. Pathogenicity was proved In vitro. Based on typical symptoms on the foliage, microscopic observations and pathogenicity test; the pathogen has been identified as Leviellula taurica, the cause of powdery mildew of chilli.

\section{References}

Blazquez, C.H. (1976). A powdery mildew of chilli caused by Oidiopsis spp. Phytopath. 66: 1155-1157.

Cerkauskas, R. F. Brown, J. Ferguson, G. and Khosla, S. (1999). First report of powdery mildew of green house pepper caused by Leveillula taurica in Canada. Pl. Dis. 83: 781.

Correll, J.C. Gordon, T.R. and Elliot, V.J. (1987a) Host range, specificity and biometrical measurements of Leveillula taurica in California J. Pl. Dis. Sci. 71:
248-251.

Jharia, H.K. Khare, M.N. and Chand, A. (1978). Chemical control of powdery mildew of chilli. Current, Res. 7: 46-48.

Koike, S.T. and Beckman, P. (2002). Characterization of powdery mildew caused by Leveillula taurica on calla lily in California. J. Pl. Dis.Sci. 86(2): 187.

Liu-AiYuan. (2002). Identification methods of resistance of pea to powdery mildew using detached leaves. Acta Phytopathologica. 29 (2):119-123.

Pickersgill, B. (1997).Genetic resources and breeding of Capsicum spp. Euphytica. 96(1): 129-133.

Sampangi, R.K. Glawe, D.A.Barlow and Mohan, S.K. (2013). First report of powdery mildew caused by Leveillula taurica on Giant Blazing Star (Menzelia Laevicaulis). J Pl. Dis Sci., 94(1): 132.

Sudha, A. and Lakshmanan, P. (2009). Integrated disease management of powdery mildew (Leveillula taurica (Lev.) Arn.) of chilli (capsicum annum L.) Arch. Phytopath. Pl. Prot. 4: 299317.

\section{How to cite this article:}

Mahmad Haneef Peshama, M.S. Dadke, B.P. Dandnaik and Zaheer Ahamed, B. 2017. Proving Pathogencity of Leveillula taurica Causing Powdery Mildew of Chilli. Int.J.Curr.Microbiol.App.Sci. 6(12): 1855-1858. doi: https://doi.org/10.20546/ijcmas.2017.612.211 